Бранислава Миладинов

brrrana@gmail.com

821.111.09-1 Ворссворт B.
https://doi.org/10.18485/ai_san_o_gradu.2018.ch11

\title{
ИСКУПЉЕНИ ГРАД: ВОРДСВОРТОВ УСНУЛИ ЛОНДОН
}

Романтичарска књижевност је место порекла представе о граду као индустријском паклу, царству лицемерја и изопачености и невеселом простору механичког рада, људског безнађа и отуђења. Вордсворт је типично виђен као један од очева оваквог погледа. Међутим, у његовој се поезији наилази на два на први поглед неспојива виђења великог града, односно Лондона. Туробној представи о могућностима метрополе да задовољи човекове духовне потребе каква се находи у Седмој књизи Прелуgијума супротставља се имагинативна визија града као живог и с Природом стопљеног бића из сонета „Спеваног на Вестминстерском мосту“. У раду се разматрају доминантни елементи ове две опречне слике града, као и могућност да се оне интегришу у јединствен идејни оквир.

Кључне речи: Вордсворт, град, епифанија, Лондон, романтизам.

\section{1. Увод}

Романтизам је најшире и примарно препознат као поезија природе: наличје ове тематске и идеолошке одреднице јесте постављање града насупрот природи. Отуда онда следи неповерење и омраза према урбанитету, на различите начине утемељена и формулисана код различитих аутора. Блејк и Вордсворт препознати су као гласоноше тог става према граду по којем је он 
место неправе, изгубљене људскости, простор принуде и неслободе, те отуђења и осујећене креативности. ${ }^{1}$ У претходном, просветитељском веку превладава позитивна слика града као узоритог поретка, као цивилизације у малом у којој цветају прогрес, просвећеност, друштвена покретљивост и слобода, напоредо са марљивим радом и специфичним урбаним уживањима. ${ }^{2}$ Дакако, у 18. веку видљиви су и сасвим другачији погледи: Дефо, Филдинг, као и његов пријатељ сликар и карикатуриста Вилијем Хогарт, те Џон Геј, аутор „Просјачке опере“ - сви редом заокупљени градом у својим делима - сугеришу суморнију, најчешће сатиричну слику порока и искварености, управо насупрот цивилизацијском идеалу. Код Русоа и његовог „злог близанца“ Лаклоа Париз је простор гламурозне празнине и маскираног зла. Блејк, особено, и у духу властите митопоијеје, у савременом граду препознаје начела организације и принуде која су оруђа лажног бога Јуризена и његовог обожаватеља - палог човека. Код Бајрона и Шелија чујни су извесни одјеци Вордсворта док метрополу опевају као место усамљености у мноштву, као простор без саосећања, где себичност замењује братску солидарност.

Сам Вордсворт ретко град узима као средишњу тему песме, као год што је град ретко и поприште њеног збивања. Такав изниман случај налазимо у два вишеструко различита његова дела, која ће у овом раду бити подробније промотрена: реч је о Седмој књизи

1 Премда је овај став мање-више опште место историје књижевности и студија културе, нешто развијенију дискусију или оштроумна запажања нуде Saklofske 2010 и Williams 1973: 79, 150.

2 Тако је на пример Волтер, иначе велики љубитељ Енглеске, видео Лондон. 
Прелуgијума и чувеном сонету „Спеваном на Вестмин-

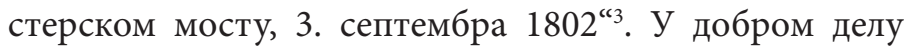
Вордсвортове поезије град се и не спомиње, мада је у неколико важних песама које носе његову песничку филозофију, антропологију и идеологију - попут „Тинтернске опатије“, „Стихова написаних у рано пролеће“ или „Оде о наговештајума бесмртности“ - град имплициран као место изван природе и њој супротно, где лирски субјект осећа пре свега терет света, изопаченог, неразумљивог, журног и бучног, света који се променио тако да га песник не осећа као свој. У том смислу, Вордсворту често припада место главног романтичарског идеолога антиурбаног песништва и једног од твораца негативног стереотипа о граду.

Међутим, Вордсвортова семантизација града не исцрпљује се у овом сврставању у таборе. Рејмонд Вилијамс чак наглашава семиналност Вордсвортовог двоврсног, па онда и парадоксалног виђења Лондона као заједнице у којој ординирају и силе реда и силе хаоса, где су на делу - истовремено или наизменце - линије уједињавања и ослобађања, заједно са силама „претње, збрке и губљења идентитета“ (1973: 151), што овај аутор види као превасходни начин на који се слика града протеже кроз књижевност од Дикенса преко Т. С. Елиота, па све до његовог времена. Негативна визија урбанитета амбивалентно је упарена са митолошком фигурацијом оріанизма који поседује извесну аутохтону силу и озрачје што изазивају и страх и фасцинацију.

У неким Вордсвортовим наративним песмама, по правилу смештеним у оквир села, град пребива као сеновито gруїge - као велики свей пун чуда и могућно-

3 У наставку текста ће се на ову песму упућивати као на „Сонет“ или „На Вестминстерском мосту“ - разумљиво, зарад лакшег језичког баратања. 
сти, неспорно примамљив али и многоструко опасан. Реч је о песмама које су махом баладе, те је представа о граду у њима пре део колективне визуре руралних протагониста него лирског субјекта. ${ }^{4}$ Типичан пример била би дуга стихована приповест „Мајкл“ („Michael“) из Лирских бaлаga, где је град у који Мајкловог сина Лука шаљу да нешто од њега постане импликован као место корозије и кварења карактера, те као легло порока што заводи и трује нејаке духове. ${ }^{5}$ У дугој стихованој причи „Жена-скитница“ („The Female Vagrant“) град је место равнодушности и незаинтересованости за ближње. Нарочит и усамљен случај у Лирским балаgама представља песма „Сањарија сироте Сузан“ („А Reverie of Poor Susan“) која се збива у граду, али чији је

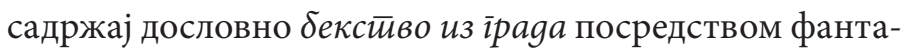
зије: девојчица насред градске вреве зачује пој дрозда (из кавеза) и то окида повратак у завичајну природу посредством маште. Ова три примера оцртавају аксиолошки и идејни оквир у каквом се град појављује у највећем броју песама насталих у најплоднијој деценији Вордсвортовог певања. ${ }^{6}$ Град је место које загушује дух вревом, жамором, буком, хитњом - ритмом који не припада духовном поретку - и које прети усамљеношћу, отућењем, дехуманизацијом и специфичним имо-

4 Питање идеолошког позиционирања и вредновања урбанитета кроз фокализацију и приповедни коментар у Вордсвортовим лирским баладама део је поигравања с традиционалном позицијом исказног субјекта, што је је једна од најпроминентнијих стратегија модификовања народне баладе код Вордсворта. Стога би ова тема захтевала образлагање сложеније но што простор и главна линија овог рада допуштају.

5 Упор. Ahearn 1971: 78, Stelzig 2011: 193.

6 Реч је о периоду од 1797. до 1807. када настају и Лирске балаge, и прва верзија Прелуgијума, као и поменути сонет, а који окончава збирка сабраних песама (Poems in Two Volumes, 1807). 
рализмом новог доба индустрије и профита, против чега је могуће борити се само изолацијом, повлачењем у приватни простор и имагинацију, у којој оживљавају духовне слике лепоте, радости и активности опажених у природи, те уверавају у сврховитост и одуховљеност света чији је човек интегрални део.

\section{2. Шетња кроз „чудовишни мравињак“}

Уобичајило се у англистичким студијама романтизма да се на Прелуgијум гледа као на Вордсвортово животно дело, премда је песникова замисао била значајно грандиознија, а овај аутобиографски спев требало је да буде нека врста увода и припреме за њу. Реч је о типично романтичарском хибрияном жанру - стихованој наративно-лирској приповести у којој се, у нарушеној хронологији и мимо уобичајеног аутобиографског значаја, ређају епизоде по сећању оцењене као формативне у развоју песничког духа. Седма од укупно четрнаест књига носи наслов Боравак у Лонgону (Residence in London) и предочава долазак тек свршеног и још о будућности неодлучног студента с Кејмбриџа у метрополу, на неку врсту распуста пре тренутка одлуке о томе „ком ће се животном правцу приволети“ (The Prelude, VII, 58-9). ${ }^{8}$ Није небитно што је позиција исказног аутобиографског субјекта на почетку ове књиге Прелуgијума одређена као бивање на йрайy, у транзи-

7 Елементи оваквог размишљања разасути су кроз ауторефлексивне песме попут „Нарциса (Као облак самотан сам лутао)“ (последња строфа), „Стихова написаних у рано пролеће“ или „Тинтернске опатије“ (стихови 23-57).

8 Реферише се на последњу верзију Прелуgијума - ону из 1850. године. Убудуће ће у библиографској парентези бити изостављен наслов дела, као и број књиге - с обзиром да су сви наводи из Седме: број стиха упућиваће на ово издање спева. Сви преводи поезије моји су и, на жалост, лишени еуфонијског аспекта оригинала. 
ционом стадијуму који претходи важном одлучивању будућности: Лондон је представљен превасходно у терминима онога што нуди и онога што ускраћује контемплативном и за песништво заинтересованом младом човеку.

На основном фабуларном плану Седма књига је структурирана као наратив о шетњи лондонским улицама у којем се извештај о виђеном комбинује с рефлексијом о опаженом и доживљеном. ${ }^{9}$ Садржај посматраног је стога вишеструко занимљив, јер у ономе чему младић сведочи доминирају два обележја или аспекта. Прву општу карактеристику града сачињавају гужва, непрекидно кретање и ужурбаност - у слици „чудовишног мравињака“ (ст. 149) иконички су сабрани различити видови непрестане акције. Други аспект је - зачудо ${ }^{10}$ - аспект забаве: улице нуде безбројне облике карневалског, циркуског и театарског ${ }^{11}$ збивања које сиренски заводе и окупирају пажњу пролазника.

Дечачка очекивања да престоница понуди сцене из романсе и историје бивају оповргнута низањем вашарских приказа и циркуских вештина, уличних

9 Каткад се ова позиција Вордсвортовог шетача доводи у везу с једним познијим типом „градског зналца“ - доколичаром или flâneur-om - каквог детаљније описује Валтер Бенјамин. Вид. Benjamin 1986: 43-70, LaRose 2006: 78.

10 Негативна карактеризација града у романтизму почива на идеји о граду као сублимату капиталистичког и индустријског доба чије је главно обележје користан и профитабилан рад: креативна доколица и несврховита уметност у таквом окружју постају сувишне, чак у радикалном поимању - штетне. Вордсвортово усредсређивање пажње на масовну забаву и спектакл тешко је не читати као визионарски увид у социокултурне векторе које ће наредна столећа само потврдити.

11 Подробнији увид у карневалски и гротескни аспект приказаног даје Stelzig 2011, а о театарској суштини предоченог града вид. LaRose 2006. 
инсценација недавних злочина, дречавог театарског одигравања историјских догађаја, маскараде, изложби и панорама, музике и певања, пантомиме и позирања. У завршном делу Седме књиге описан је вашар Светог Вартоломеја где се каталошки побрајају „чуда“ попут албиноса, дивова, трбухозбораца и дивљих звери, изопачених несрећника и мајстора ретких вештина који заједно сачињавају „скупштину чудовишта“ (ст. 718). Гомила се тиска у потрази за спектаклом, узбуђењем, уживањем, фасцинирана аномалијама и реткостима, свиме оним што је насупрот обичном и свакодневном. Позориште, које заузима значајно место у овом галиматијасу, представљено с дозом ироније, јер је реч о нападно костимираном, стереотипном и претераном сценском извођењу снажних и драматичних догађаја, али му посматрач-приповедач признаје извесну, премда слабачку моћ да побуди имагинацију. Нарочити призор представља сцена којом се забава повлачи с улице у затворени простор, а репрезентује свет у вешто израђеној минијатури. То је симулакрум обухваћене, прегледне, схватљиве, уоквирене стварности - управо супротан аморфној, стално променљивој, збуњујућој реалности метрополиса и његових улица.

Оно што је заједничко свим овим призорима јесте да се оснивају на имитацији стварности, да њима доминирају маска и појава, насупрот огољеној аутентичности и суштини, те да представљају ексцес - сйек-

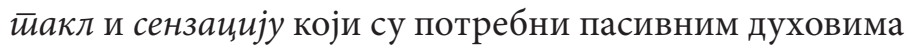
да их прену из летаргије материјалистичког и механичког живљења у опресивним условима капиталистичког рада и стицања. Чудовишност као перверзна карактеристика како самих призора, тако и њихове горљиве публике уписује се у доживљај самог locus-а. Лондон који песник посматра није предочен као индустријски 
град - он то доиста и није на начин северњачких центара индустрије, попут Манчестера, Бирмингема или Ливерпула. Међутим, Вордсворт подразумева и на другим местима говори ${ }^{12}$ о великом граду као простору у којем су људи принуђени да раде - униформне, механичке и репетитивне послове који исцрпљују и који одузимају време и енергију, не остављајући могућности за креативан рад и живу имагинацију.

Лондон је такође приказан као место у које се слива читаво човечанство: он је „микрокосмичка верзија“ народа света (Hugo 1987: 2), чији је облик збирка узорака с различитих поднебља и из разноврсних слојева познате стварности. Каталошка набрајања битно су стилско средство у Седмој књизи Прелуgujyмa: ${ }^{13}$ од списка грађевина које се надају оку посетиоца (мостова, катедрале Светог Павла, Вестминстера, Тауера, итд.), преко већ поменутих призора уличне забаве, па до пописа „свих примерака човека“ (ст. 236) у који улазе разне нације - од северњачких Швеђанина и Руса, јужњака Француза и Шпанца, преко америчког Индијанца, Маварина, Малајца, Ласкара, Татарина, Кинеза, до црнкиње у муслинској хаљини (ст. 21928). Хоризонтала империје упарена је с вертикалом друштва: премда није представљена 'енциклопедијски', она упућује на различите професије и занате, као и на

12 Најчувеније је место из Предговора Лирским балаgама где директно повезује гомилање људи у градовима и нове узусе рада са „жудњом за необичним догађајима“ и снажним стимулусима, што као једну од последица има занемаривање великана попут Милтона и Шекспира у корист „безумних романа, изопачених и глупих немачких трагедија, те поплаве залудних и екстравагантних стихованих приповести“ (Wordsworth 1974: 735).

13 Више о употреби каталога - као начина да се у сцену уметне наратив, те као средства којим се манифестује песнички труд еквивалентан раду градског становништва вид. La Rose 2006: 76, 79. 
нишче који су обележје улица метрополе - проститутке, просјаке, сецикесе... Састав овог каталога сугерише стицај трговаца, људи из колонија и егзотичних путника по незнаним пословима, као и криминалног, подземног града у граду, чиме се Лондон одређује не само као космополитска колекција света у малом, као занатски, меркантилистички и пословни центар, већ и као пакленско место палих становника. Испод и наспрам лудичког и егзибиционог вида ситија, 'каталогизоване' су и емблематичне приказе дебело нашминкане и урешене лаке женске с дететом анђеоске лепоте упркос којој је оно већ осуђено на пропаст, сиромашног занатлије с болесним чедом којем такође нема спаса и, коначно, иронични врхунац у фигури слепог просјака усред свег тог визуелног вртлога. Дакако, сама Вордсвортова биолошка, хербарска лексика додатно подцртава каталошку перцепцију мноштвености и многоликости што је сабрана и изложена градском шетачу.

Метод предочавања, односно наративна техника, у Седмој књизи Прелуgијума привлачи пажњу на себе. Аутодијегетички приповедач комбинује и стапа опажање и представљање с ауторефлексијом, што је Вордсвортов уобичајени поступак. Међутим, овде је кретање атрибут и града и посматрача: приповедач хода градским улицама, ${ }^{14}$ а објекти његовог погледа такође су у покрету. Алберто Габијел скреће пажњу на врло оригиналан начин на који тече предочавање градског кретања, поредећи га са знатно каснијим модернистичким и експерименталним техникама базираним на но-

14 Већ је и само кретање исказног субјекта неуобичајено: Вордсворт је често пародиран због специфичне констелације у својим песмама које доиста почињу тек онда кад се лирски субјект физички умири - застане у шетњи, одмара се под дрветом или лежи на каучу. 
вим знањима из оптике ока, које своје исходиште коначно имају у филму. Посматрач је у покрету, а његова субјективна перспектива је несистематична - његов је поглед насумичан и клизи преко објеката које сусреће, што резултира синтаксом кинематографске нарације: прекидност, прелазак с предмета на предмет има облик набрајања, односно паратактичког везивања. Тиме се с једне стране чува известан ниво објективности у субјективном, идиосинкратичном погледу, а с друге стране се кроз набрајање интерполирају потенцијални наративи које читалац прилагођава властитим схемама. ${ }^{15}$ Сем тога, овај поступак се врло уверљиво може поредити с нарочитим филмским поджанром који се одређује као „дан у животу великог града“, а узорити примерак представља Човек с филмском камером (1929) Дзиге Вертова (Gabriele 2008).

Простор града превасходно је представљен улицама којима се тиска гомила, а с њом и сам приповедач. Но, правац њиховог пружања, како запажа Иго, иде од центра ка периферији: ове градске жиле изводе из града у предграђе, а одатле у села на која се град ослања као на изворе хране. Центрифугалност је општи принцип који управља како животом града, тако и духом оних што у њему обитавају (Hugo 1987: 1). Зракасто простирање из средишта ка спољашњости аналогно је силницама што дух шетача-посматрача (и приповедача) вуку напоље, у поље чулног - пре свега визуелног. Ова изотопија део је, с једне стране, негативног вредновања утицаја градског окружја на индивидуу чија је пажња стално усмерена на оно изван себе, у простор снажних чулних подстицаја - а не у правцу самоспознаје. С друге

15 Сличан поступак обележава још две велике „симфоније града“: Дос Пасосов Менхейн Трансфер и Елиотов Прелуgијум. 
стране, центрифугалност градског простора омогућава успостављање везе између града и села: упућивањем на транзициону зону град се шири према селу, у природу, а наглашеност овог радијалног континуума и неоштре границе завршетка града биће основа за сагледавање метрополе као интегралног дела Природе у „Сонету“.

Исказни субјект Прелуgијума је делимично субјект аутобиографије и особеног Bildung-a - како поднаслов каже, реч је о развоју духа - у правцу песника, с неизвесним исходом. Вордсворт сам није живео у Лондону, али га је редовно посећивао, почев од времена студија на Кејмбриџу. ${ }^{16}$ Он, дакле, није Лондонац, чак није ни становник града - у том смислу он не припада месту које предочава и доживљава. Та измештена перспектива младића који ступа у непознато и упознаје свет да би утврдио властито место у њему део је образовног процеса. Подједнако је важно и то што је он сиромашни апанажер који не партиципира у свету капиталистичког рада, ${ }^{17}$ те је као доколичар без утилитарног позива и на тај начин стављен у позицију

16 Аутобиографски и фабуларно, ова књига Прелуgијума описује конкретни боравак у престоници из 1791. године - три године после прве посете - а фингира први сусрет с великим градом. Но, будући да овај спев није права, конвенционална аутобиографија, те да веродостојност животописа није доминантно начело приказивања, није на одмет споменути да је визија Лондона сачињена од више Вордсвортових посета, односно представља колаж реминисценција и рефлексија о типичним и одредбеним обележјима престонице обједињен специфичним епистемолошким ставом.

17 Исказни субјект јасно ставља на знање да је његова (пр)оцена неусловљена чежњом за тријумфом. У уводним стиховима се чак спомињу скромност и штедљивост, уз одсуство „опасних страсти“ и „личне амбиције“ које би се намиривале у метрополи (управо супротно од јунака Bildungsromana, нарочито реалистичких). 
gруі̄ō или страног. На провери је такође и комунални потенцијал великог града: романтичарски идеал $\delta р а \bar{u}-$ сиива љуяgи и солидарности међу ближњима изразит је у Вордсвортовој антропологији. Резултати овог „истраживања" у великој су мери поразни по метрополу. На почетку је запањен је сепарацијом и изолацијом у којој суседи не познају један другог (ст. 115-18), а у завршници Седме књиге, ходајући усред гомиле, казује самом себи „Свако лице које / Крај мене прође је тајна“ (ст. 628-29). Метропола не успева да се конституише као заједница, она је колекција засебних примерака лишених сопства, без колективног духа и саосећања - место самовања и отуђености.

Град је, ипак, творевина људске воље и организације - задивљујући пример цивилизаторске моћи. Наспрам претходно назначеног мањка, у Седмој књизи Прелуgијума видљив је известан 'вишак' дејства који се осећа у граду, дејства што не потиче од људског организационог принципа, ${ }^{18}$ већ се може приписати самом метрополису као фигурацији која надилази пуки скуп људи и њихових активности. Овакво виђење града логички је основ за ревизију слике метрополе у имагинацији - оне каква се находи у „Сонету“ - о чему ће доцније бити речи. Град поседује властиту потенцију, надилазећи тако концепт пуког скупа својих становника. Моћ лоцирана у биће града упућује на одуховљену пројекцију метрополиса која се онда природно отвара начелу персонификације и митологизације, што је карактеристично за модерни (и нарочито - реалистички и модернистички) третман града.

18 Иго нотира Вордсвортово „опажање које наликује Блејковом из песме 'Лондон' по коме град, иако се претпоставља да је организован људском вољом, у суштини генерише властиту моћ, способну да притисне читаву заједницу унутар себе“, што илуструје стиховима 593-597 (Hugo 1987: 4). 


\section{3. Визија уснуле нагости}

Сонет „Спеван на Вестминстерском мосту, 3. септембра 1802.“ исказује једно сасвим другачије виђење и осећање Лондона. Нимало елегантан наслов евидентно сугерише важност проживљености изложеног доживљаја: његова изразита аутобиографичност подцртава тачку порекла у стварном искуству. ${ }^{19}$ Структура Вордсвортових песама готово се увек ослања на схему по којој се прво излаже непосредан емоционални, односно искуствени доживљај - који можемо условно назвати стварносним или биографским, а следи му потом контемплативно или медитативно употпуњење и уопштавање - чиме се докончава имагинативни, поетски рад. Такав је случај и овде: сапет у строгу сонетну форму, Вордсворт у октави песнички извешитава о опаженом, док у сестини призор тирансиендира и бива мапиран унутар имагинативне слике света. Садржај, пак, стварносног искуства, такав је да по правилу изазива известан шок и прекид равнодушног бивања. У овом сонету редовно су херменеутичку пажњу привлачили управо аспекти разлике и тензије: онеобиченост,

19 Критичари и тумачи ће редовно уочавати дискрепанције на плану биографије: посматрање града с Вестминстерског моста $y u$ стиину се, сва прилика, догодило раније, у јулу, када су се Вилијем и његова сестра Дороти кретали ка Доверу да би отпутовали у Француску. Потом су се, током септембра, задржали неко време у Лондону - о томе сведочи и Доротина дневничка белешка која садржи известан број констелација необично сличних онима изложеним у песми (Wordsworth, D. 2002: 123), као и Вордсвортово сведочење из позних година. Секундарни значај датума непосредног доживљаја или настанка замисли о сонету у односу на датум његовог „састављања“ и коначног уобличења, поетички битно упућује на прожетост аутентичности партикуларног искуства и његове универзализације у имагинативном обликовању, из чега се у романтизму изводи истинитост поезије. 
односно неуобичајени вид познатог који се на нов начин трансформише у имагинативни увид и зачуђеност лирског субјекта који доживљава извесну епифанију. Брукс ће инсистирати на изненађењу као доминантном осећању које прати парадоксалну структуру стечене спознаје (Brooks 1960: 5), Дејвис наглашава напетост између објективне дескрипције познатог и емоционалне реакције која га преображава (Davis 1970: 18-19), дочим Хартунг и Викер инсистирају на хармонизовању опрека као емотивној и идеолошкој доминанти песме (Hartung 1952: 202; Wicker 1955: 4). Експлицитно или не, сваки од ових тумача, као и још неколицина непоменутих, тај састојак дисконтинуитета поимају разумевајући „Сонет“ као песму која Лондон представља несагласно идеолошкој доминанти везаној за град присутној у Вордсвортовом песништву, односно као песму у којој се на зачудан начин казује управо супротно од препознатљиве романтичарске антиурбане парадигме. Другачије речено, „Сонет“ се по правилу чита као контраст у односу на Седму књигу Прелуgијума, при чему као да се прећутно подразумева да је лирски субјект „Сонета“ идентичан приповедачу спева - те сам изненађен властитим утисцима и увидом.

За разлику од перипатетичког фокализатора из Седме књиге Прелуgијума, исказни субјект „Сонета“ стоји непомично на мосту који раздваја северну и јужну обалу Темзе, као и западни од источног Лондона. Истовремено, река је повезница урбаног са руралним, континенталног с морским, овдашњег и прекоморског. ${ }^{20}$ Временски је казивач ситуиран у познолетње свитање, пошто је окончана ноћна градска врева, а дневна још

20 У извесном смислу, у интерпретативну игру би могли ући и познати подаци о путу у Француску који уоквирују настанак ове песме. 
није отпочела. И просторна и временска стајна тачка лирског субјекта носе атрибуте прелаза, односно бивања између или на йpaīy - још не у лондонској свакодневици и не сасвим на лондонском тлу. Стајање на мосту отвара поглед, несуспрегнут зидовима грађевина којима су оперважене улице, баш насупрот проматрачкој позицији шетача из Прелуgијума. Тренутак спокоја у којем град још није отпочео захуктале активности подједнако је инверзан ситуацији из великог спева. Перспектива из које се испева сонет повлашћена је: обичне и свакодневне ствари задобијају „чар новине“,21 а актуелно открива свој трансцендентни вид. ${ }^{22}$

Сонет започиње уписивањем неупоредиве земаљске лепоте градског призора кроз унеколико зачудну негацију којом се постулира јединственост и врхунски карактер ових квалитета, уз опаску да само душевна тупост може остати нетакнута величајном племенитошћу и узвишеношћу опажљивог (ст. 1-3). Дакако, већ

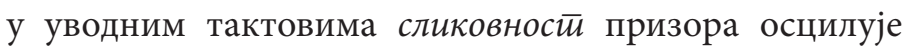
на граници надчулног: земља показује најбоље у свом репертоару, а сама жива душа пријемник је ове ретке поруке. Дејвис запажа извесну емоционалну апстрактност и бледуњавост употребљених дескриптора (fair,

21 Колриџ открива договор по којем је Вордсвортов задатак за Лирске балаgе био да „да чар новине свакидашњим стварима и да побуди осећања аналогна натприродном тако што ће побудити пажњу духа из летаргије навике и усмерити је на лепоту и чудесност света пред нама“" (Coleridge 1921: 145): то је доцније у критици прихваћено као лапидарни мото Вордсвортовог антимиметичког пројекта.

22 Дакако, на овом месту је тешко не дозвати у памет Андрићев „Сан о граду“ и аналогну епифанију: са скровитог балкона, као повлашћеног места, пред његовим се умним очима отвара надстварни и свеукупни Дубровник. 
touching, majesty), ${ }^{23}$ чији смисао се може тражити у иницијалној загрцнутости лирског субјекта - запањености на којој инсистира Брукс (1960:5) - услед које доживљај још не долази до адекватног израза. У наредним се, пак стиховима песма пуни конкретнијим детаљима и то у два правца: први управља ка персонификованој слици Ситија одевеног у одору јутарње светлости, а други ка миметичком приказу градских елемената, те његовог просторног пружања и уоквиравања.

Вордсворт у Предговору Лирским балаgама изравно критикује механичко и аутоматско коришћење персонификације одомаћено у осамнаестовековној британској поезији (Wordsworth 1975: 736), пажљиво је користећи за нарочите случајеве сликовног и вербалног артикулисања снажних осећања. Готово неизрецива лепота града даље се у песми развија кроз парадоксалну слику места одевеног у тишину и „лепоту јутра“ а притом нагог, сасвим изложеног погледу, лишеног сваке маске. ${ }^{24}$ Хаљина зоре, светлост и сјај (bright, glittering) и - нарочито, с обзиром на негацију што аутоматски активира властиту супротност - ваздух без дима (smokeles air, ст. 8) имплицирају постојање другачије, сиве и димљиве, „дневне“ градске одоре. Ова песничка слика недвосмислено успоставља дијалог и са темом театарског преоблачења, карневала и маскараде

23 Он је разумева као један пол напетости наспрам конкретности песничког доживљаја (Davis 1970: 19).

24 Нужно је споменути да је у Прелуgијуму Лондон женског рода, како је иначе конвенционално уобичајено у енглеском језику; у „Сонету“ нема изравне прономинализације, али „хаљина“ или „одора“ (garment, ст. 4), заједно с чином заогртања у провидност, формирају слику која призива традицију прекривања и обнаживања женског тела. Незгода је што су у српском и „град“ и „Лондон“ мушког рода - но, не треба губити из вида феминизацију именице која у систему језика није родно обележена. 
која доминира представом Лондона из Седме књиге Прелуgијума: пред изненађеним очима лирског субјекта скинуте су облоге и велови, а светлост је открила јасновиду обнаженост. Персонификација ће се наставити у сестини - у кретању реке која поседује вољу, слици уснулих кућа и метафори моћног срца. Сувишно је спомињати да персонификовањем метрополе Вордсворт предузима чин оживљавања и одуховљења, неопходан за покушај његове интеграције у свеукупну органску прожетост природе.

Миметички аспект приказаног метрополиса сачињен је као каталог предметности - махом грађевина - које формирају контуру града на позадини неба: „бродовље, куле, куполе, театри и храмови“ (ст. 6). Њихово простирање, односно протежност, наглашени су глаголом - они „се отварају ка пољима и према небу“ (ст. 7). Хоризонтално пружање у призор увлачи руралне пределе до којих град сеже, у које се претапа и који јесу његов истински земни оквир: избор предлога unto наглашава одсуство јасних граница и континуитет града и поља - лексичке суме села и природе.

Вертикалност кровова упућује поглед навише, комплетирајући конкретно, премда сажето, микрокозам града у оквиру неба које у Вордсвортовој поезији понајвећма реферише на временитост - оно је емблем космичких кружења што одређују време вегетативне природе и свега постојећег. Недовољно конкретна блистава приказа наге женске фигуре у велу светла добија специфичан и унеколико фрагментаризован облик онога што је изграђено и што, с једне стране, обухвата просторну експанзију и историјско трајање, а с друге реферише на коегзистентност с околним руралним пределима и дивљом природом под паском неба и времена самог. Сам песнички каталог градских елемената 
(и објеката лирског погледа), својим садржајем, нужно изискује херменеутичку пажњу: немогуће је одолети пориву да се набројани ентитети тумаче као симболи трговине и економије, политике, религије, уметности и правде (или, уопштено, институција) - дакле, цивилизацијских тековина и активности: Лондон је средиште нације и империје и њен симбол. ${ }^{25}$ Као што је случај с персонификацијом, тако ће и овај каталог имати свој аналогон у сестини, где ће низ који чине елементи дивље природе - „долина, стена ил' брег“ (ст. 10) - успоставити паралелизам и суштинску истоврсност градског и природног пејзажа у првом сјају јутра.

Сестина почива на две негативне стиховне реченице и узвику у последњем дистиху. Прва негација има карактер опште тврдње:

Never did sun more beautifully steep

In his first splendour, valley, rock, or hill. (ст. 9-10)

Никада сунце није лепше натопило

Својим првим сјајем, долину, стену ил' брег.

Јасно је успостављена веза с почетком песме: као што земља у првом стиху није имала да прикаже ништа лепше од града у свитање, тако ни сунце никад није лепше осветљавало неки призор. Песма се варљиво упућује у локо-дескриптивном правцу, успостављајући примат лепоте града унутар јединственог универзума у којем сад већ равноправно у поредби стоје urbs и природа. Посебност и јединственост предоченог спектакла готово да није потребно ни коментарисати - искључне речи попут anything и never у потпуности повлашћују супериорност призора и на хоризонталном просторном и на вертикалном темпоралном плану, у космичкој

25 Премда се већина критичара који су се позабавили „Сонетом“ дотиче овог 'каталошког' стиха и тумачи га у узајамном сагласју, детаљније вид. Sucksmith 1976: 114; Saklofske 2010: 312. 
игри земље и сунца над Лондоном и око њега. Међутим, друга негација се окреће од света и понире у субјекта:

Ne'er saw I, never felt, a calm so deep! (ст. 11)

Никад не видех, нити осетих, тако дубок спокој!

И овај наглашени изричај везује се за почетак песме, тачније за други стих контрастом: лирски субјект, будући будне душе и живе имагинације, снажно је такнут не само величанственошћу призора, већ и његовим укупним смислом што доноси дубоки мир. Дублетом гледања и осећања повезани су ум и свет у хармоничном затишју града и природе.

Између две наведене негације и завршнице песме уметнута је „река која тече по својој милој вољи“ - слободна од зауздавајућег саобраћаја, и сама персонификована, сагледана као вољно биће. Река је, уједно, и једини протагониста кретања у блиставој и статичној визији. Овај стих завршава се двотачком: он представља на први поглед алогичну најаву за зазивање бога и нову визију парадоксално оживљеног метрополиса.

Dear God! the very houses seem asleep;

And all that mighty heart is lying still! (ст. 13-14)

Боже драги! саме куће као да спавају;

А читаво то моћно срце мирно лежи!

Слика уснулог града - и то града као скупа заспалих кућа, а не људи у сну - део је персонификујућег импулса којим се Лондон фигурише као биће, да би у завршном стиху био метафорички замењен „моћним срцем“, чиме се слика надопуњује функцијом назначеном каталогом грађевина на хоризонту: метропола је срце, метонимија Британије, средиште и погон читаве државе.

Међутим, слика „моћног срца које мирно лежи“ провоцира оправдану интерпретаторску нелагоду: немогуће је отети се дојму смрти која је утиснута у по- 
следњи призор. „Први стих сугерише да је дама уснула. Потоњи би могао значити да је град попут леша,“ вели Џозеф Хилис Милер ${ }^{26}$ у свом тумачењу ове песме (Miller 1971: 306), објашњавајући да је ово доиста тако зато што у граду нема људске свести: човек је суспендован, ампутиран из ове повлашћене перспективе песникове. Људи у тренутку зоре нису ту да производе дим, да реку зауздавају у своје сврхе (те она клизи по својој вољи), а песник учествује у миру који постоји само у његовом одсуству: „он је ту и није ту, попут властите утваре“. На миметичко предочавање метрополе јукстапонирана је семиоза која осцилује „између свести и природе, присуства и одсуства, кретања и мира“ (1971: 307). Песник је виделац фантазијског убиства града Лондон је умртвљен да би могао бити сагледан као целина и као део веће целине света у имагинацији, чији се простор находи између живота (који је мимеза и референција) и смрти (која је фигурација, симболизација и апстракција).

\section{4. Закључак}

Један од средишњих песничких проблема укупног Вордсвортовог песништва јесте питање могућности и начина имагинативног увида у емпиријску стварност. Природа је истовремено гарант и водич - и нека врста портала - до спознаје трансцендентне природе света. Она је одуховљена и смислена, хармонична унија свега живог, примордијално устројство суштин-

26 Иако Хилис Милер уме да зазвучи као да је први уочио да је метропола мртва, већ је Брукс о томе писао, а за њим и сваки следећи критичар. Милер, пак, феномен смрти ставља у средиште свог тумачења. 
ски обележено активношћу и радошћу. Сваки човек обдарен је имагинацијом - менталном моћи којом се продире иза варљиве појаве чулно-материјалног света - а њена слободна дејственост, удружена са неспутаном осећајношћу и непрестаном рефлексијом о себи и универзуму обећање је пуног и складног, потенцијално стваралачког, живљења. Сусрет имагинације с природом извор је сваке истините мисли, посебно оне поетске. Вордсвортова опредељеност за песништво тражила је хранитељско окружење за уобразиљу и нашла га у селима Језерске области, која пружају миран, готово идиличан, живот старинског, комуналног типа.

Међутим, центар културних, уметничких, политичких и научних догађања, као и полазиште за сваку стваралачку амбицију - а све је то Вордсворта занимало и привлачило - била је, дакако, престоница. Сем тога, Лондон је у то време већ деценијама прекомилионски град, седиште највеће империје модерног доба, авангарда индустријализацијског света, представљао је неку врсту чуда које је нужно осмотрити и промислити. Важност суочења с великим градом осведочена је посвећивањем читавог засебног одељка духовно-развојног наратива Лондону. Јасно је да Прелуgијум подастире слику која је обележена фрагментарношћу и дистрактивношћу метрополе као друштва, њеном преференцијом за јефтине и духовно умртвљујуће забаве основане на сензационализму и спектаклу, да непрекидна активност која га карактерише није друго до безумно присилно јурцање у нужди и напор да се стицањем обезбеди дигнитет. Разнолико мноштво које затиче на улицама састављено је од изолованих појединаца што се узајамно не познају, па онда ни не саосећају, отуђени од властитог аутентичног сопства и природе, неслободни и унижени, принуђени да појавом прикри- 
вају мањак суштаствености. Лондон остаје топоним иза којег не стоји колектив, чију мноштвеност не интегришу комунални принципи и чија је иконичка слика слепи просјак из Седме књиге Прелуgијума. Раздешеност људске заједнице могла би се по визуелном набоју поредити с Бошовом инферналном визијом или са сатиричним приказама експресионистичког сликарства, мада се не може оспорити доза фасцинације и привлачности коју метрополис код Вордсвортовог приповедача изазива. Та мешавина страха и дивљења, екстатични апетит доконог шетача и посматрача, наликује на младалачки однос према природи описан у „Тинтерској опатији“ или песми „Брање лешника“ („Nutting“) - пре но што зрелост допусти да је природа доведе до смиреније и складније осећајности.

Сонет „Спеван на Вестминстерском мосту“, прочитан у овом раду на позадини Прелуgијума и у релацији према њему, представља, у извесном смислу, тај зрелији корак у поимању великог града, који се десио неизазван и нетражен - како вазда бива с просветљењима. Нарочити тренутак и посебна стајна тачка обезбедили су онеобичени вид истог града, па се његов идеализацијски потенцијал за лирског субјекта променио: монструозни механизам трансформисан је у организам потопљен у лепоту света и уроњен у природу. Реч је, недвосмислено, о стасавању духовне моћи да се град обухвати и упише у мрежу релација неопходних аутентичном имагинативном бићу: да се сагледа као недељив од природе, да се у њему уочи могућност лепоте, а да му се притом не одузму или укину свакодневне функције. Метрополис је conditio sine qua non модернитета, а Вордсвортов сонет је аргумент против тезе о романтичарском ескапизму: иако увиђа духовни банкрот модерног друштва, оличен управо у животу 
града, песник чини напор да имагинацијом продре у дубину слике и допре до могућности искупљења урбанитета. Умртвљеност града, неопходну за целовитост имагинативне визије, стога нема потребе разјашњавати перверзном танатофилијом или некрофилским импулсима, већ ваља смрт разумевати симболички као чин наративног довршавања - у(c)покојења - без којег нема целовите приче, о чему Вордсворт говори у „Есеју о епитафима“.27 У том духу, песма „На Вестминстерском мосту“ може бити читана не као, како вели Вордсворт, анатомска дисекција леша, нити као портрет мирног модела, већ као приказ карактера који је:

[...] попут дрвета [виђеног] кроз нежну маглу или светлуцаву измаглицу што одуховљује и полепшава. [...] То јестие истина, и то највишег реда; јер, неспорне ствари нису очевидне иако су постојале; но се предмету који се гледа кроз овакав медиј, делови и сразмере доводе у нарочити вид што је раније само несавршено или несвесно био опажен. („Essay upon Epitaphs“, Wordsworth 1974: 731)

Испоставља се, онда, да метрополис није наказна аномалија на лепом лицу света, већ биће за које постоји нада да би могло бити хуманизовано.

\section{Извори}

Wordsworth, William. Complete Poetical Works (with intruduction and notes). Ed. Thomas Hutchison (1901), Rev. ed. Ernest de

27 Циклус песама о Луси кореспондира с темом смрти која чином довршавања, уобличења и перфектуирања тек чини могућим

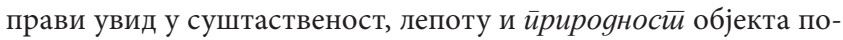
сматрања и љубав као осећање према њему (тачније, њој - како год и у нареченом сонету). 
Selincourt (1936). Oxford: Oxford University Press, 1974.

Wordsworth, William. The Prelude: 1799, 1805, 1850 (Norton Critical Editions). Eds. Jonathan Wordsworth, M.H. Abrams and Stephen Gill. London: W.W. Norton \& Company, 1979.

Wordsworth, Doroty. The Grasmere and Alfoxden Journals. Ed. Pamela Woof. Oxford: Oxford University Press, 2002 [1851 $\left.{ }^{1}\right]$.

Литература

Андрић, Иво. „Сан о граду“. Сйазе, лица, ӣреgели. Сабрана дела Иве Андрића, књ. Х. Београд: Удружени издавачи, $1981\left[1923^{1}\right]$.

Ahearn, Edward J. „The Search for Community: The City in Hölderlin, Wordsworth, and Baudelaire". Texas Studies in Literature and Language, 13:1 (1971): 71-89

Benjamin, Walter. „Paris Drugog carstva u Baudelairea“. Estetički ogledi. Zagreb: Školska knjiga, 1986 [1939¹]

Brooks, Cleanth. The Well Wrought Urn. Studies in the Structure of Poetry. London: Harvest Books, 1960 [1949ㄹ]

Coleridge, Samuel Taylor. Biographia literaria, Or, Biographical Sketches of My Literary Life and Opinions. London : J. M. Dent, $1921\left[1817^{1}\right]$

Davis, C.G. The Structure of Wordsworth's Sonnet 'Composed Upon Westminster Bridge. English: Journal of the English Association, 19:103 (1970): 18-20.

Edgecombe, Rodney Stenning. „Wordsworth's 'Sonnet Upon Westminster Bridge' and Night I Of Young's Night Thoughts". Notes and Queries, 45:2 (1998): 191.

Gabriele, Alberto. „Visions of the City of London. Mechanical Eye and Poetic Transcendence in Wordsworth's Prelude, Book VII“. European Romantic Review, 19:4 (2008): 365-384.

Hartung, Charles. „Wordsworth on Westminster Bridge: Paradox or Harmony?"“. College English, 13: 4 (1952): 201-203.

Hugo, François. „The City and The Country: Books VII And VIII of Wordsworth's 'The Prelude'. Theoria: A Journal of Social and Political Theory, 69 (1987): 1-14.

LaRose, Nicole. „Wordsworth's Urban Theater and the Imaging of Community“. Interdisciplinary Literary Studies, 7: 2 (2006): 74-88.

Miller, J. Hillis. „The Still Heart: Poetic Form in Wordsworth“. New Literary History 2.2 (1971): 297-310. 
Peer, Larry H. (ed.). Romanticism and the City. New York: Palgrave Macmillan, 2011.

Saklofske, Jon. Between History and Hope: „The Urban Centre of William Blake and William Wordsworth". Smith, Greg T. and Judith Owens, Glenn Clarck (eds.). City Limits: Perspectives on the Historical European City. Montreal, Kingston: McGillQueen's University Press, 2010. 300-324.

Smith, Greg T. and Judith Owens, Glenn Clarck (eds.). City Limits: Perspectives on the Historical European City. Montreal, Kingston: McGill-Queen's University Press, 2010.

Stelzig, Eugen. „Wordsworth's Invigorating Hell: London in Book 7 of The Prelude (1805)“. Peer, Larry H. (ed.). Romanticism and the City. New York: Palgrave Macmillan, 2011. 181-195.

Sucksmith, Harvey Peter. „Ultimate Affirmation A Critical Analysis of Wordsworth's Sonnet, 'Composed upon Westminster Bridge', and the Image of the City in 'The Prelude". The Yearbook of English Studies, 6 (1976): 113-119.

Wicker, C.V. „On Wordsworth's Westminster Bridge Sonnet“. The News Bulletin of the Rocky Mountain Modern Language Association, 9.1 (1955): 4.

Williams, Raymond. The Country and the City. New York: Oxford University Press, 1973.

\section{Branislava Miladinov}

\section{THE CITY REDEEMED: WORDSWORTH'S DORMANT LONDON}

\section{Summary}

Romantic literature is widely presumed as the point of origin of the negative image of the city, represented as an industrial inferno, realm of hypocrisy and perversion, as well as dreary zone of mechanical labour, hoplessness and alienation. Wordsworth is typically considered not only proponent, but also a source of such an account. However, his poetry hosts two seemingly opposite representations 
of the city. Gloomy prospect of London's aptitude to satisfy human spiritual needs presented in Book seven of The Prelude is contrasted to an imaginative vision of enlivened, organic and with Nature interfused city of sonnet „Composed upon Westminster Bridge“. In this paper, dominant aspects of both facets are taken into account, as well as possibility that the revealed paradoxical views are to be interrelated into an integral frame of mind. 